\title{
Securitizing the Muslim Brotherhood: state violence and authoritarianism in Egypt after the Arab Spring
}

Article

Accepted Version

Pratt, N. and Rezk, D. (2019) Securitizing the Muslim Brotherhood: state violence and authoritarianism in Egypt after the Arab Spring. Security Dialogue, 50 (3). pp. 239-256. ISSN 1460-3640 doi: https://doi.org/10.1177/0967010619830043 Available at https://centaur.reading.ac.uk/82778/

It is advisable to refer to the publisher's version if you intend to cite from the work. See Guidance on citing.

To link to this article DOI: http://dx.doi.org/10.1177/0967010619830043

Publisher: Sage

All outputs in CentAUR are protected by Intellectual Property Rights law, including copyright law. Copyright and IPR is retained by the creators or other copyright holders. Terms and conditions for use of this material are defined in the End User Agreement.

www.reading.ac.uk/centaur 
Central Archive at the University of Reading

Reading's research outputs online 


\title{
Securitizing the Muslim Brotherhood, Legitimizing State Violence and Renewing Authoritarianism in post-Arab Spring Egypt ${ }^{1}$
}

By Nicola Pratt (University of Warwick) and Dina Rezk (University of Reading)

Accepted for publication in Security Dialogue on 17 December 2018

\begin{abstract}
Unprecedented levels of state violence against the Muslim Brotherhood and its widespread acceptance by Egyptians following the July 2013 military coup have been under-examined by scholars of both critical security studies and Middle East politics, reflecting implicit assumptions that state violence is unexceptional beyond Europe. This article explores how the deployment of such levels of violence was enabled by a securitization process in which the Egyptian military successfully appropriated popular opposition to Muslim Brotherhood rule, constructing the group as an existential threat to Egypt and justifying special measures against it. The article builds on existing critiques of the Eurocentrism of securitization theory, alongside the
\end{abstract}

\footnotetext{
${ }^{1}$ The authors wish to thank the 3 anonymous reviewers, Christopher Browning (University of Warwick) and João Nunes (University of York) for their careful reading of the manuscript and their constructive feedback and advice. Any errors are the fault of the authors.
}

Research for this article was funded by AHRC standard grant, AH/N004353/1, 'Politics and Popular Culture in Egypt: Contested Narratives of the 25 January Revolution and its Aftermath' 
writings of Antonio Gramsci, to further refine its application to non-democratic contexts. In addition to revealing the exceptionalism of state violence against the Muslim Brotherhood and highlighting the important role of nominally non-state actors in constructing the Muslim Brotherhood as a threat to Egypt, the article also signals the role of securitization in re-establishing authoritarian rule in the wake of the 2011 uprisings. Thus, we argue that securitization not only constitutes a break from 'normal politics' but may also be integral to the reconstitution of 'normal politics' following a period of transition.

\section{Introduction}

This article deploys securitization theory to understand the unprecedented levels of state violence in Egypt following the military's ousting of Egypt's first democratically elected president, Mohammed Morsi, in July 2013, and, in particular, the massacre by security forces of over 800 civilians (and possibly as many as 1000) on 14 August 2013 with minimal domestic outcry and opposition. Challenging realist assumptions that security 'is something more than a natural response to a self-evident threat' (Nunes 2012: 346), the Copenhagen School has advanced the notion of securitization as the discursive construction of an issue or an entity as an existential threat, enabling the application of 'exceptional' measures outside of the normal political process, if such a construction resonates with a 'significant audience' (Buzan et al 1998).

However, the application of securitization theory beyond its traditional Eurocentric domain raises important questions about what constitutes 'normal politics' versus 'exceptional measures' in non-democratic contexts (McDonald 2008, Aradau 2004), 
and the degree to which the theory is limited by its 'Westphalian straitjacket' (Wilkinson 2007). In line with other authors, this article posits that securitization theory is applicable in non-Western contexts, subject to refinements; namely, the conceptualization of 'special politics' not as a break from democratic politics but rather as a break from the rules that non-democratic regimes depend upon to govern (amongst others, Vuori 2008, Holm 2004); and, the rejection of a Eurocentric-model of state-society relations (Wilkinson 2007), which assumes that civil society is autonomous from the state.

The article begins by discussing securitization theory and its applicability to the Egyptian context. First, it examines what precisely constitute 'the rules' under an authoritarian regime, drawing on the Gramscian concept of hegemony to understand the institutional, ideological and social embeddedness of authoritarianism. The article argues that a 'break from the rules' occurs when rulers deviate from the 'authoritarian bargain,' thereby rendering state violence unacceptable in the eyes of a critical mass within society, as occurred in the run-up to the 25 January 2011 uprising. Second, in order to clarify the relevant actors and their respective roles in the securitization process, the article explores the definition of state and non-state actors in non-Western contexts, utilizing the Gramscian concept of civil society in order to conceptualize the blurred lines between these categories.

Following this, the article delineates the securitization process that culminated in the August 2013 massacre. First, it draws attention to the important role played by nonstate actors in constructing the Muslim Brotherhood as a threat to Egypt and, thus, paving the way for the rehabilitation of the military as a legitimate securitizing actor, following its huge loss of popularity in the post-Mubarak period. This process effectively enabled the military to launch a coup against former President Morsi on 3 
July. In this respect, the article demonstrates the instrumental role of civil society in the securitization process, as well as highlighting the difficulties of distinguishing between state and non-state actors or indeed, co-opted and independent actors vis-àvis the state.

Second, it analyses two key speeches by the military that successfully appropriated the already existing anti-Muslim Brotherhood discourse as well as elements of the demands of the 25 January 2011 uprising. These speeches can be conceptualized as 'securitizing moves' that sought to justify the use of exceptional measures against deposed president Morsi and his supporters. In particular, General Abdel Fatah ElSisi's 23 July speech, calling on Egyptians to give the military 'a mandate to fight terrorism', and the subsequent mobilization of Egyptians on 26 July, provided crucial political cover for the Rabaa and Nahda square massacres on 14 August.

Finally, the article considers the role of this successful securitization process in normalizing and institutionalizing new levels of state violence and repression, which have been used beyond the Muslim Brotherhood, targeting youth activists, civil society organizations, trade unionists and critics of the Sisi regime (Hamzawy 2017, HRW 2017). In this respect, the securitization process can be understood as central to efforts to re-establish authoritarian rule in the wake of the 2011 uprisings. Thus, the article argues that securitization not only constitutes a break from 'normal politics' but may also be integral to the reconstitution of 'normal politics' following a period of transition. We conclude with reflections on what the case of Egypt may contribute to theorizing securitization in non-Western contexts, as well as what securitization theory can contribute to understanding the establishment and maintenance of authoritarian regimes. 


\section{Securitization in Non-Western/Non-Democratic Contexts}

Securitization theory has mainly developed through its application to case studies from Europe (Bilgin 2011: 401) and, consequently, there has been considerable debate over whether and how securitization theory can be applied to non-Western and/or non-democratic contexts. The primary objection made to using securitization theory in authoritarian contexts is the distinction between 'normal' and 'exceptional', whereby it is assumed that 'exceptional' measures constitute a departure from the norm of deliberative liberal-democratic politics (Aradau 2004, Browning and McDonald 2011, McDonald 2008, amongst others). If securitization is understood as 'a means of moving certain issues beyond the democratic process of government' (Vuori, 2008: 65), then how can it apply to states where democratic processes do not exist or are weak? A related question is whether securitizing actors in non-democratic contexts are even obliged to seek societal consent for their actions or whether they simply can rely on coercion.

Questioning the applicability of securitization theory in non-democratic contexts assumes that authoritarian rule is arbitrary and despotic, reflecting long-standing orientalist tropes about non-European countries (Sadowski 1993). In Egypt, like several other states in the Middle East region, the post-independence state has enjoyed widespread powers of control and surveillance enforced by a robust coercive apparatus (Bellin 2004). Moreover, the emergency law, which was in place almost continuously between 1967 and 2011, gave state authorities wide powers to detain and prosecute citizens. ${ }^{1}$ Yet, state violence has not been used in an arbitrary fashion at least not until the later period of Mubarak's rule. Moreover, one cannot understand the longevity of authoritarian regimes like that of Egypt through the prism of coercion alone. Whilst the state's coercive apparatus and use of repression has undoubtedly 
contributed to the maintenance of authoritarianism over decades, nonetheless, prolonged coercion entails high costs to regimes. Rather, successive regimes have primarily relied upon a number of non-coercive practices to govern, including institutional arrangements, economic inducements, as well as ideology. Therefore, as Juha Vuori argues, rather than viewing 'special politics' as a break from democratic politics, 'special politics' should be understood as a break from the rules that nondemocratic regimes depend upon to govern (2008: 69). In this respect, the 'depoliticizing effect' of securitization, whereby an issue is moved from the arena of 'normal politics' to that of 'special politics', should be understood in relative terms, and 'therefore can be observed in both democratic and undemocratic societies' (Greenwood and Waever 2013: 486).

We suggest that Antonio Gramsci's concept of 'hegemony' allows us to further conceptualize the rules by which authoritarian regimes govern beyond liberal democratic modes of citizenship. According to Gramsci, any dominant class exercises power not only through mechanisms of coercion, such as the police, military and the legal system, but also through consent, using a variety of non-coercive means, including political institutions, economic/material benefits and culture (Gramsci 1971: 258). In order to be successful, hegemony must appear to be in the interests of wider society and not only those of the dominant class (Gramsci 1971: 161). In postindependence Egypt, one of the most important elements of regime hegemony has been an 'authoritarian bargain' between rulers and ruled, in which citizens have ceded political and civil freedoms in return for social welfare and other economic benefits, such as job security and subsidized essential goods and services (Ayubi 1995, Heydemann 2007, Pratt 2007a, Sadiki 1997). Mass organizations, political parties, elections and parliaments have also served to co-opt political opponents (amongst 
others, see, Ayubi 1995, Blaydes 2010, Brownlee 2007, Lust-Okar 2005, Posusney and Penner Angrist 2005, Schlumberger 2007). Ideologically, post-independence regimes have successfully garnered legitimacy by portraying themselves as the guarantors of Egyptian sovereignty and national progress against both internal and external threats (for example, see Pratt 2004, 2005 and 2007b).

The ability of regimes to use repression has been dependent upon winning consent amongst citizens. First and foremost, as Terry Eagleton argues, 'the coercive institutions of a society ... must themselves win a general consent from the people if they are to operate effectively' (1991: 114). Alongside this, regimes have generally deployed coercion within the parameters of the authoritarian bargain, rather than arbitrarily, targeting repression against those, mainly political opponents, who have attempted to change the terms of the bargain by challenging the regime's political and ideological supremacy. In this regard, the Islamist movement has been viewed as the greatest threat by Egyptian regimes and, thus, it has experienced the lion's share of state violence. Under the regime of Gamal Abdel-Nasser, the Muslim Brotherhood was proscribed and hundreds of its members were imprisoned, with some tortured and executed (Mitchell 1969/1993: 105-162). The regime portrayed the organization as a lackey of feudalists and colonialists, threatening to destroy the progressive nationalist gains of the Egyptian 'revolution' of 1952 (ERTU 1965, Mitchell 1969/1993: 126127). When Anwar Sadat came to power in 1970, he allowed the re-emergence of the Muslim Brotherhood as a counter-balance to supporters of the former president (Ayubi 1993: 56). Yet, following sharp criticism of Sadat's peace treaty with Israel, the authorities arrested over 1500 individuals, mainly Islamists, but also secular nationalists and leftists, provoking an Islamist militant to assassinate the president in 1981 (Ayubi 1993: 57). Under the regime of Hosni Mubarak, the Muslim 
Brotherhood was tolerated, although not legalized. It was allowed to operate within the political system, contesting parliamentary elections, as well as standing for elections to the boards of professional syndicates (El-Ghobashy 2005, Rosefsky Wickham 2013). However, in response to the Brotherhood's electoral success and popularity, the regime moved to contain the organization, periodically arresting its members and even trying some before military courts (Rosefsky Wickham 2013). The Brotherhood were also targeted as part of the state's wider crackdown against violent Islamist groups during the 1990s (HRW 1995, 1996; Kienle 2001: 93-96). ${ }^{2}$

Historically therefore, large-scale state violence and, in particular, the use of lethal force, in post-independence Egypt, whilst violating international human rights laws, was not indiscriminate within the terms of the 'authoritarian bargain'.

However, in the run-up to the 2011 uprising, police repression became more arbitrary and wide-ranging (Abdelrahman 2017, Al-Nadim 2002, 2006, Kandil 2012, Rashed 2016). This coincided with the introduction of neoliberal economic reforms after 1990, which led to the withdrawal of the social and economic benefits underpinning the post-independence 'authoritarian bargain', provoking social unrest amongst workers, farmers, and even the once quiescent middle classes (Abdelrahman 2014). Moreover, there was evidence that this level of repression was increasingly viewed as illegitimate by sectors of the population (Ismail 2012). Bloggers began highlighting the torture and sexual abuse perpetrated in police stations and many victims spoke out about their experiences. The spark that lit the fuse was undoubtedly the murder of a young, middle-class man, Khaled Said, who was brutally beaten to death by police officers in the middle of the street in June 2010. Photos of his mutilated and broken face circulated on social media, provoking widespread outrage. A Facebook group titled, "We are all Khaled Said" facilitated unprecedented online mobilisation, 
particularly of digitally active youth, who in turn played a key role in organizing the 25 January 2011 protests (Chick 2010, Alaimo 2015). The 2011 uprising and the willingness of Egyptians to face police violence suggests the extent to which regime hegemony had broken down and that the use of state violence was no longer viewed as legitimate by large sections of the population. Therefore, whilst authoritarian regimes are able to break the rules governing the use of state violence, nonetheless, in order for regimes to continue to govern, these 'special politics' (Vuori 2008) must be seen as legitimate by a critical mass within society. Against this back-drop, we posit that securitization theory enables a detailed exploration of the process through which state violence became relegitimized after July 2013.

Blurred boundaries between state and societal actors under authoritarian regimes

A second question concerning the applicability of securitization theory in nonWestern/non-democratic contexts relates to the common assumption that securitizing actors are state elites and that there is a clear divide between state and non-state actors (Wilkinson 2007). Such assumptions may be traced to Western political thought, which posits civil society as an autonomous realm distinct from the state, acting as a check on state power (Cohen and Arato 1992). However, scholars have shown that under authoritarian regimes, the boundaries between state and civil society are often blurred (Ottaway 2004, Shah 2008) and the latter may lack the independence of their Western counterparts, due to restrictive laws and regulations, civil society-state patronage networks and the corporatization of interest groups that may serve to bolster authoritarian regimes (Lorch and Bunk 2017). Similarly, the literature on civil society in the Middle East highlights the sector's lack of independence, its historic politicization and the 'uncivil', indeed authoritarian tendencies amongst many civil 
society actors (Zubaida 1992, Norton 1994, 1995, Abdelrahman 2002). Indeed, a more nascent literature has introduced the concept of 'civil society coups' in which governments have been able to co-opt non-state groups to support a military intervention (Encarnación 2013, Dorman 2013).

Nonetheless, whilst civil society in the Middle East (and other authoritarian contexts) may not resemble or behave like civil society in Western democracies, nonetheless, it is important not to reproduce orientalist discourses that essentialize non-Western societies as inherently despotic, blaming the absence of a European-style civil society (Sadowski 1993). Historically, there are many examples of non-state groups in the Middle East challenging oppression and demanding justice and rights, including constitutional movements, human rights organizations, feminists and even religious actors (amongst others, Chalcraft 2016, Norton 1995 and 1996, Pratt 2007a, Waltz 1995). The 25 January 2011 Revolution was enabled by the existence of a network of civil society activists, which had emerged following a decade of contentious antiregime activism (Abdelrahman 2015, Beinin 2014). The 2011 uprising gave further impetus to the growth of civil society, with large numbers of Egyptians sustaining a high-level of mobilization over many months in order to hold to account Egypt's postMubarak rulers and to expand civil freedoms.

Therefore, civil society includes a range of types of organizations that cannot be easily categorized into state/non-state or co-opted/independent. It is perhaps more useful to conceptualize civil society, in line with Antonio Gramsci, as a space in which both the state and non-state actors engage and interact (Hardig 2015: 1134; see also Gramsci 1971: 262). For Gramsci, civil society is not only comprised of actors and institutions but constitutes a sphere through which the ruling classes attempt to establish their hegemony in order to rule through consent (Femia 2001; see also 
Ayubi 1995, Pratt 2007a, Hardig 2015). Hence, civil society is organically linked to the state, rather than being autonomous, and should be viewed as a key terrain upon which the battle for the legitimacy of a ruling regime, including its security practices, is fought. In Egypt, the post-2011 period witnessed an intense struggle within civil society, culminating with the July 2013 military coup and the ousting of former president Mohamed Morsi, as the next section explores.

\section{The Securitization of the Muslim Brotherhood: 2012-2013}

How is it that such spectacular levels of state violence after July 2013 came to be widely accepted by Egyptians? This section explores the process of securitizing the Muslim Brotherhood, which culminated in the use of lethal force against supporters of former president Mohammed Morsi, including the massacres of 14 August 2013. We trace this episode of securitization back to the narrow victory, on 30 June 2012, of Mohammed Morsi, in Egypt's first free presidential elections. Whilst the Copenhagen School has conventionally focused on the role of security elites in designating threat (McDonald 2008), we demonstrate that the major protagonists in the construction of the MB as a threat were not official elites but a range of nominally non-state actors in civil society-youth activists, women's rights and human rights advocates, opposition political parties, artists, journalists, writers and media personalities — who eventually coalesced around the 'Tamarod' [rebel] campaign. As the following discussion will show, some of these actors were supportive of the army but many were both anti-military and anti-Morsi, seeing either option as a threat to the aims of the 2011 revolution. This section will demonstrate that irrespective of their level of co-option, the combined discourses of these different sectors of civil society created a 'window of opportunity' for the military to rehabilitate itself as a legitimate 
securitizing actor, providing an enabling context for the 3 July 2013 coup and, in turn, the August massacres and other episodes of lethal force against supporters of deposed president Mohammed Morsi.

The period between Morsi's election and his ousting was marked by ongoing opposition and protests, which became increasingly violent over time. There is little doubt that many of the criticisms against Morsi's rule were warranted. He pushed through a constitution drafted by a controversial constituent assembly, failed to reach out to the opposition in the face of growing polarization, used Mubarak-era tactics to stifle media criticism, oversaw ongoing violations by security personnel, including the use of disproportionate violence against protesters and torture of detainees. He failed to stem hate speech and sectarian attacks against Copts and other religious minorities and to present a coherent vision to address Egypt's economic crisis and demands for social justice (Abou-El-Fadl 2013). More broadly, the Muslim Brotherhood demonstrated political opportunism throughout the post-Mubarak transition process, siding with the military against popular demands for more deep-seated political transformations. They assumed that they would be able to take control of the state by replacing the existing personnel, underestimating the entrenched networks within state institutions and the strength of their antipathy towards the MB, supported by Saudi Arabia and the United Arab Emirates, who feared the regional repercussions of the rise to power of the organization (El-Sherif 2014).

However, the ways in which many of these criticisms were articulated operated to demonize Morsi and the Muslim Brotherhood as an exceptional threat to Egypt. In this regard, a range of actors drew upon long-standing historical tropes, dating back to the days of the regime of the Free Officers, portraying the Muslim Brotherhood as essentially untrustworthy, secretive, violent, treasonous and antithetical to modern 
politics (for example, see Mitchell 1969/1993). For example, one of the most influential critics of Morsi was satirist Bassem Youssef, whose show El-Bernameg [The Show] was the most watched programme in the history of Arab television. In one notable episode, Youssef launched a pointed attack against Islamists as 'merchants of religion', thereby implying that the group exploits Islam for their own narrow interests. His show thrived on mocking the Muslim Brotherhood as well as ordinary Egyptians who supported Morsi’s government (Fisher 2014). More widely, supporters of Morsi and the MB were often called 'sheep' by their opponents, suggesting that they were unthinking followers who merely did what they were told by the MB leadership (for example, Shiulke 2012; Carr 2013a). Another commonlylevelled accusation against the Muslim Brotherhood was that they were seeking to 'Brotherhood-ize' (ikhwana, in Arabic) the state, that is, to impose their hegemony over state institutions, implying that the organization was threatening the 'true', authentic character of the Egyptian state (Shahine 2012; Abdel-Baky 2013a).

Criticisms of the presidency increased notably after Morsi issued a constitutional declaration on 22 November 2012, appointing a new public prosecutor and giving himself what were regarded by many as excessive powers by making presidential decrees immune to judicial oversight (Associated Press 2012). Whilst Morsi claimed that these measures were necessary to protect the revolution and transition to a constitutional democracy, he was accused of appointing himself as 'Egypt's New Pharaoh' (Spencer and Samaan 2012). Amr Hamzawy, a liberal member of the dissolved parliament and prominent intellectual described Morsi's regime as an 'absolute presidential tyranny' and claimed that 'Egypt is facing a horrifying coup against legitimacy and the rule of law and a complete assassination of the democratic transition' (Kirkpatrick and El Sheikh 2012). On 24 November 2012, thirty-five 
political groups formed the National Salvation Front, an opposition coalition led by prominent pro-democracy politicians such as Mohamed el-Baradei and Hamdeen Sabahi, as well as supporters of the former Mubarak regime, such as Amr Moussa. They called for the president to rescind his decree and demanded a more representative constituent assembly. Both the name of this new front, and the sudden alliance of groups that had previously failed to work together effectively to contest the electoral power of Islamists in the past, communicated a moment of urgency and threat. At the street level, Morsi's declaration resulted in large protests and a sit-in in front of the Presidential Palace, which were violently attacked by Morsi's supporters. In response to widespread protests, Morsi annulled the declaration, but insisted on proceeding with a snap referendum on the new constitution, despite the failure of the Constituent Assembly to reach consensus on a number of key issues, resulting in opposition and independent members walking out. The proposed constitution was actively opposed by a range of civil society actors, including opposition political parties, youth activists, women's rights and human rights groups and artists. A strongly-worded statement from 24 Egyptian human rights organizations expressed concern at what they perceived as 'attempts by the dominant parties within the Constituent Assembly to undermine the concept of the modern state and to import the Iranian model of the theocratic authoritarian regime in a "Sunni mould" (Several Egyptian Human Rights Organizations 2012). The constitution, which was passed in a popular referendum with a 63 percent majority but a low voter turn-out of only 33 percent, certainly fell short on guaranteeing human rights and women's rights (HRW 2012). However, as one observer argued, 'The 2012 Egyptian constitution is not a blueprint for an Islamic state'; rather it suffered from attempts to merely amend the 
1971 constitution rather than creating a new constitution, due to the political considerations of those drafting it (Albrecht 2013).

The more significant outcome of the constitution drafting process was to further exacerbate the tensions between supporters and opponents of the Muslim Brotherhood. Anti-government protests became regular occurrences and frequently ended in clashes between protesters and security forces and, increasingly, between protesters and supporters of Morsi. The private media, mainly owned by former regime sympathizers, undertook a concerted campaign to demonize Morsi and the Muslim Brotherhood, accusing them of 'taking over' the state to pursue their own narrow interests, deploying 'militias' against anti-Morsi protesters and threatening Egyptian identity with their 'foreign' attitudes towards religion (Abdalla 2014: 20; Elmasry 2013; Yahya 2014). The theme of Morsi's threat to Egypt was also expressed in relation to his foreign policy. His close relations to Qatar were viewed with suspicion and rumours were spread in the media that the wealthy Gulf state was planning to 'buy' the Suez Canal (Ezzat 2013) —Egypt's most strategic asset and a symbol of national pride since its nationalisation in 1956.

The constitutional crisis was an important turning point and provided the army with a window of opportunity to gradually relegitimize itself as a securitizing actor after its loss of popularity during its rule between 2011 and 2012. From this point on, the military made a number of statements that stopped short of explicitly demonising the Brotherhood but sought to re-establish the army as the rightful guarantor of Egypt's security. For example, following the clashes outside the Presidential Palace in December 2012, then Minister of Defence Abdel Fattah El-Sisi highlighted the danger of polarization and urged dialogue, stressing that the alternative was 'a dark tunnel that will result in catastrophe' and warning that unless their advice was heeded, 'the 
nation as a whole will pay the price' (Hussein 2012). After the constitutional referendum, El-Sisi described the army as the 'true guarantor of the country's security' and 'an integral part of this great people.' In the aftermath of clashes between protesters and police in Egyptian cities along the Suez Canal in January 2013, in which more than 50 people were reported dead, El-Sisi warned that the political crisis 'could lead to a collapse of the state' (BBC 2013a). In leaked recordings in March 2013, El-Sisi was heard telling air force pilots that 'the armed forces belong to the people alone', thereby distancing the army from the presidency. Meanwhile, Chief of Staff, General Sidqi Sushi, announced that the army was keeping 'an eye on what is going on in the country', assuring the public that 'if the Egyptian people ever need the armed forces, then they will be on the streets in less than a second', clearly signalling that the army was poised to intervene to end the political crisis (Ibrahim 2013).

On 28 April 2013, the Tamarod (meaning 'rebel') campaign was officially launched with the goal of collecting 15 million signatures by 30 June (the anniversary of Morsi's presidential victory), calling for early elections. It was presented as a grassroots initiative, with supporters collecting signatures from ordinary citizens throughout Egypt, and was soon endorsed by the National Salvation Front. By early June, it claimed to have collected 15 million signatures and was calling for mass protests on 30 June (Abdel-Baky 2013b). Mahmoud Badr, the co-founder and spokesperson, explained in an interview that, 'Tamarod was established to bridge the gap between the people and the opposition, which failed to win the hearts and minds of millions of Egyptians because of the lack of skills to build grassroots support. Simply we are the grassroots force of the opposition groups' (Abdel-Baky 2013b). Since then, evidence has emerged that the movement operated with the approval and 
support of the military and security agencies as well as supporters of the former Mubarak regime. Leaked recordings of conversations between Egyptian military figures reveal that the group drew funds from a bank account administered by the Ministry of Defence and replenished by the United Arab Emirates (Ketchley 2017: 113), indicating the powerful regional interests also at play. Tamarod also received support from the Mubarak-era business elite, and in particular from billionaire Naguib Sawiris, who had been pursued for tax evasion by the Morsi government. Moreover, in the run-up to the 30 June, the military deployed its forces to the streets, assuring Egyptians that they were positioned to protect the protesters and not the government (Ketchley 2017: 117-119). However, these links were, for the most part, concealed and many revolutionary and anti-military activists, such as the Revolutionary Socialists and 6 April Movement, supported Tamarod, viewing it as a means of reviving the revolutionary process (Abdel-Baky 2013b, Ketchley 2017: 110). Indeed, Tamarod replicated the modes of mobilization of the 25 January 2011 uprising and reiterated the goals of the revolution, including justice for those killed by security forces since 2011 and dignity for Egyptians, which, according to them, the Morsi regime had failed to deliver (BBC 2013b).

On 30 June, millions of Egyptians heeded Tamarod's call and went down to the streets. Protesters outside the presidential palace were heard calling on the army to remove Morsi and chanting 'the people and the army are one hand' (Kingsley 2013), recalling a key slogan of the 2011 uprising against former president Hosni Mubarak. The protests continued over the next few days and calls for the army's intervention grew louder (Carr 2013b). Whilst groups such as the 6 April Movement and the Revolutionary Socialists marched for a third alternative to the MB and the army, they were outnumbered by the crowds cheering for the military's intervention (MadaMasr 
2013a). Some of the support for the army clearly came from 'co-opted' actors. Walter Armbrust's examination of the role of Tawfiq Okasha, former NDP member and host of the satellite television show Al-Fara'een, indicates the instrumental role of such nominally 'non-state' actors, in rallying support for the removal of Morsi and the return of the military (Armbrust 2013). However, much appeared to come from 'ordinary citizens' who were frustrated with Morsi’s rule (Abdel-Baky 2013b, Ibrahim 2013).

\section{The military moves in}

The stage was thereby set for a military intervention. On 1 July, General El-Sisi issued an ultimatum to Morsi to solve the political crisis within 48 hours or the army would impose their own roadmap. Then, on 3 July, El-Sisi declared that the army had suspended the constitution and deposed the president in order to 'end the state of conflict and division' and to 'ensure the construction of a strong and coherent Egyptian society which does not exclude any of its members and trends'. El-Sisi claimed that the Brotherhood's rule had led to 'social divisions and tensions' which represented 'pivotal challenges and dangers facing the homeland'. According to Sisi, President Morsi had refused to enter into a 'national dialogue' and had inflicted 'harm on the state's national and religious institutions', 'intimidat[ing] [and] threaten[ing] the Egyptian people' (El-Sisi 2013a). By contrast, El-Sisi affirmed the 'historic and patriotic role' of the army and reiterated that the military had 'exerted tremendous efforts, both directly and indirectly, to contain the domestic situation and conduct national reconciliation'. Alluding to his privileged role as former Director of Military Intelligence, he stated that he had 'on several occasions, presented a strategic assessment of the domestic and foreign levels, addressing the most pivotal challenges and dangers facing the homeland on the economic, security, political, and social 
levels'. He reported that he was acting in cooperation with 'certain political and social figures', referring to the coalition of opposition political parties, youth movements and other groups as well as the Coptic Church and Al-Azhar, who stood with the army in removing Morsi, thereby emphasizing that the army was not acting in its own interests, but with the support of a range of actors all united for the sake of the Egyptian nation. Announcing that the army 'could not turn a deaf ear or a blind eye to the calls of the [...] the Egyptian people for help' and was obliged to answer the 'demands of the revolution ... from all the corners of Egypt', El-Sisi evoked the role of the army in standing with the people against Mubarak during the 18 days of the 25 January 2011 uprising (El-Sisi 2013a). The success of this televised speech in reestablishing the military's legitimacy as a securitizing actor was evidenced by the lively celebrations of Egyptians protesting in Tahrir Square (Chulov and Kingsley 2013).

In response, supporters of Morsi continued their sit-ins and protests around the country. In the days that followed, there were several incidents of the use of lethal violence by security agencies against pro-Morsi protesters. Civil society actors contributed to justifying this violence through their ongoing demonization of the Brotherhood. For example, Ahmed Hawari, a member of the Dostour Party, headed by Mohammed El Baradei, said, 'I wish I could condemn the security forces for using excessive force, but I can't. [...] this is not a peaceful demonstration or a political action. [...] The Brotherhood is not opposing Sisi or the government — it is opposing the people. There is no place for [the Brothers] in the Egyptian society unless they cleanse themselves' (Afify 2013). Even media personalities like Bassem Youssef who later spoke out against the military, coalesced around a residual hostility to the Brotherhood. In a tweet on 5 July, the satirist accused: 'MB leadership [of] sending its 
youths to die at army HQs to victimize themselves against the world. Blood for publicity. Cheap. \#not_a_coup' (Fisher 2014).

El-Sisi's second major speech, also broadcast live on Egyptian television, was made during the Military College graduation ceremony on 23 July and was the clearest one yet in manifesting the Schmittian politics of 'enmity, decision and emergency' (Williams 2003: 515). The speech followed days of violence between opponents and supporters of Morsi, in which the army and the police had failed to intervene effectively. Moreover, the evening before, a bomb attack outside a police building in the provincial city of Mansoura killed a police conscript and injured 19 officers and civilians, and was described by a government spokesman as 'an act of terrorism' (MadaMasr 2013b, 2013c; see also EIPR 2014). In his speech, El-Sisi asked 'all honest Egyptians to mass in the streets this Friday' to 'give me, the army and police', 'the mandate and order that I confront violence and potential terrorism' (El-Sisi 2013b). The general constructed diametrically opposed camps: 'Honest Egyptians' standing with the army and the police versus the perpetrators of violence and terrorism - understood as the Brotherhood and supporters of Morsi. El-Sisi claimed that by going to the streets on Friday, Egyptians would show 'the world their will as they have done before' alluding to the mass demonstrations of 2011 that removed Hosni Mubarak from power and reminding protestors of the army's support during the 18 days (El-Sisi 2013b). The call for people to mass in the streets to 'mandate' the army to confront 'political violence and terrorism' served to present the special measures as the 'will of the people' and the army as acting at the behest of this popular will.

Signalling the success of El-Sisi's speech act, on 26 July 2013, millions of Egyptians responded to his request and assembled in Tahrir Square, the symbol of the 25 
January 2011 uprising, as well as other public squares around the country, in support of the army. The 'day of mandating' provided the popular and political cover for the new regime to crush the Muslim Brotherhood and Morsi's supporters. On 30 July, the cabinet 'delegated the interior ministry to proceed with all legal measures to confront acts of terrorism and road-blocking', understood as the on-going sit-ins by Morsi supporters in Rabaa and Nahda squares (Ahram Online 2013). At daybreak on 14 August, the police moved to disperse the sit-in sites in an operation that took approximately 12 hours and killed at least 817 and possibly more than 1000 (HRW 2014). This was followed by a series of repressive measures against the Brotherhood accompanied by widespread and almost universal condemnation of the organisation and its political wings in media circles. Alongside Morsi, leading members of the organisation were rounded up and imprisoned. A number were also sentenced to death. This violent repression of the Brotherhood was endorsed by a significant proportion of the population (Black and Kingsley 2013) and the Brotherhood came to be regarded as 'beyond the pale' for any possible political reconciliation or reintegration into Egyptian political and social life (Morsy 2013).

\section{Securitization and the Renewal of Authoritarianism after 2013}

This section argues that the securitization of the Muslim Brotherhood not only enabled the use of exceptional measures against the organization but also functioned to re-establish authoritarian rule in the wake of the 25 January 2011 revolution. As Joshua Stacher argues, state violence has been essential to the remaking of regimes in the post-Arab Spring era (2015). Not only did massive levels of state violence against the Brotherhood constitute a break from 'normal politics' but this section demonstrates how it has also been central to the reconstitution of 'normal politics' 
following a period of transition. In effect, the use of state violence against the Brotherhood has paved the way for creating a new 'authoritarian bargain' in which Egyptians have traded political freedoms--this time for security, rather than socioeconomic benefits.

As many observers of Egypt have highlighted, since July 2013, the El-Sisi regime ${ }^{3}$ has widened the sphere of repression beyond the Muslim Brotherhood to include anyone who expresses criticism of the regime, particularly human rights groups, journalists and those participating in peaceful protests, such as workers and students, including those who were initially supportive of the army's ousting of Morsi (Hamzawy 2017, HRW 2017, Guerin 2018). This repression was enabled by the introduction of a raft of new laws and legal amendments in the wake of the summer of 2013 (Hamzawy 2017). Following the introduction of a law in November 2013 outlawing protests without a permit, many high profile activists associated with the 25 January 2011 Revolution were arrested and imprisoned, such as, Alaa Abdel-Fatteh, Ahmed Douma, Mohamed Adel and Mahinoor Masry (Soliman and Nour 2016, Guerin 2018). In August 2015, after the assassination of the state prosecutor, the government introduced a new terrorism law, which included unprecedented measures to gag the media and offered impunity for security and military personnel in waging their 'war on terror' (HRW 2015). As a result, over 400 websites have been blocked and journalists have been jailed (HRW 2018). There have been exceptional numbers of political prisoners, mass death sentences and dramatically increased numbers of enforced disappearance and cases of torture (Amnesty International 2014; Howeidy 2015; HRW 2017; HRW 2018). The Egyptian Commission for Rights and Freedoms documented at least 1,500 enforced disappearances between 2014 and 2018 (cit. in Guerin 2018) and seventeen new prisons have been built to accommodate the 
unprecedented numbers of prisoners (Guerin 2018). In 2017, El-Sisi signed into law new restrictions on NGOs that significantly undermine their independence and freedom and implicitly criminalize the work of human rights organizations as a result of vaguely-worded articles (HRW 2018). Many activists have left Egypt, fearing that they would be targeted (Soliman and Nour 2016). Individuals have resigned from political parties, which have generally failed to create any meaningful opposition to the regime's increasing authoritarianism (Cox 2016, Hamzawy 2017). The institutionalization of such levels of state violence and coercion means public dissent has become a high risk activity. Protests—although not completely quashed—have become increasingly rare.

These draconian measures have been justified in the name of protecting 'the people' from terrorism and safeguarding Egypt's territorial integrity (El-Sisi 2014). Despite the fact that the military and its supporters framed the 3 July coup as the salvation of the 25 January 2011 revolution, since then, a narrative has emerged that has recast the 2011 uprising as a longstanding conspiracy to destroy the Egyptian state. There has been an incessant media discourse, promoted by the regime, depicting Egypt to be in a state of permanent emergency and the victim of various conspiracies aimed at state collapse, perpetrated by the Muslim Brotherhood, Islamist insurgents and foreign governments (Abdelrahman 2017: 193, Hamzawy 2017, Shams El-Din 2015). Human rights groups, in particular, are accused of acting on behalf of foreign powers to undermine the nation. Alongside this, the regime has supported a 'culture of informing' in which ordinary citizens are encouraged to report suspicions to the police (Abdelrahman 2017: 194; Gresh 2014). In January 2018, the Ministry of the Interior released a cartoon inciting Egyptian children to bypass their parents and report anything suspicious directly to the police (Dahan and al-Mossallami 2018). 
Although El-Sisi easily secured a second term in office in 2018, nonetheless, he is facing growing dissatisfaction and discontent from different sections of the Egyptian population over the poor state of the economy (Guerin 2018). There have been ongoing workers' strikes and protests, alongside small, but nonetheless important, demonstrations against dramatic increases in the cost of living, as well as significant opposition to El-Sisi's policy to transfer sovereignty over the Red Sea islands to Saudi Arabia (Charbel 2017, Ketchley and El-Rayyes 2017, MadaMasr 2016, amongst others). The ongoing attacks on Coptic Christians by violent jihadists affiliated with Islamic State, resulting in hundreds of deaths, have angered the Coptic community (Qiblawi and Jones 2017). Yet, whilst El-Sisi faces levels of discontent not imagined in 2013-2014, nonetheless, the current regime and the 'authoritarian bargain' upon which it is constructed remain intact for the foreseeable future, buttressed by fears of chaos and/or a return to the rule of the Muslim Brotherhood.

\section{Conclusion}

This article has sought to refine securitization theory for non-democratic contexts and to shed new understandings on the use of state violence in post-Arab spring countries through an exploration of the Egyptian case. Building on the work of Juha Vuori (2008) that conceptualizes securitization as the use of security logic to break existing rules, the article highlights the utility of the Gramscian concept of hegemony to conceptualize 'the rules' beyond the democratic process to include socially-embedded bargains and ideological imbrications between state and citizens. Building on existing scholarship on Egyptian politics, the article argues that post-independence regimes deployed state violence to uphold an authoritarian bargain, in which citizens ceded civil and political rights in return for social and economic rights. Once that bargain 
began to unravel as a result of neoliberal economic restructuring, state violence was no longer viewed by citizens as legitimate, thereby paving the way for the outbreak of the 25 January 2011 uprising. Hence, this article has argued that the widespread acceptance of the unprecedented state violence unleashed against the Muslim Brotherhood, following the ousting of former president Mohammed Morsi on 3 July 2013, should be understood as indicative of a successful securitization process.

Moreover, the article has highlighted the crucial role of non-state actors in the process of securitization. It was non-state actors who led the way in constructing the Muslim Brotherhood as an exceptional threat to Egypt, thereby enabling the re-constitution of the military as a legitimate securitizing actor. Therefore, the article demonstrates that a Eurocentric dichotomy of state versus society simplifies securitization dynamics in non-democratic contexts. We suggest that the Gramscian concept of civil society allows us to view the lines between state and non-state, co-opted and independent actors as fluid and blurred and to understand civil society as a hybrid space in which both state and non-state actors operate. The Tamarod campaign aptly embodies this hybridity: its leaders were co-opted by the military, but the campaign itself was supported by a range of actors including influential media personalities ranging from the pro-military Tawfik Okasha to the more independent Bassem Youssef, and even staunch anti-military activists, such as the 6 April Movement. Irrespective of whether actors were independent or co-opted, the combined effect of their discourses within civil society helped the military to take decisive action in July 2013 and justify their repressive practices in terms for which their audience was well primed.

Finally, the Egyptian case demonstrates the utility of securitization theory in shedding new light on the processes of counter-revolution and renewal of authoritarianism in the post-Arab spring era. A focus on the discourses of both security and political elites 
as well as a range of non-state actors may reveal new dynamics underpinning the dramatic increase in the use of state violence, thereby complementing existing institutional and materialist analyses. Specifically, the article signals the role of securitization in re-establishing authoritarian rule in the wake of the 2011 uprisings through the (re)constitution of a new authoritarian bargain. More broadly, the application of securitization theory to non-democracies can help to open up new avenues of research into the processes by which security logics are used to enable and sustain authoritarian regimes; a task that is perhaps more urgent now, than ever before.

\section{References}

Abdalla R (2014) Egypt's Media in the Midst of Revolution, Washington DC: Carnegie Endowment for International Peace, https://carnegieendowment.org/files/egypt_media_revolution.pdf (accessed 18 October 2018).

Abdel-Baky M (2013a) Defending the Centre Ground, Al-Ahram Weekly, 410 April, http://weekly.ahram.org.eg/News/2103.aspx (accessed 16 October 2018).

Abdel-Baky M (2013b) Something Big Will Happen on 30 June, Al-Ahram Weekly, 13-19 June, http://weekly.ahram.org.eg/News/2985.aspx (accessed 9 February 2018).

Abdelrahman M (2015) Egypt's Long Revolution: Protest Movements and Uprisings, London: Routledge 
Abdelrahman M (2017) Policing neoliberalism in Egypt: the continuing rise of the 'securocratic' state. Third World Quarterly 38(1): 185-202.

Abdelrahman, M (2002) The Politics of 'Uncivil Society' in Egypt, Review of African Political Economy 29 (91): 21-36.

Abou-El-Fadl R (2013) Mohamed Morsi Mubarak: The myth of Egypt's democratic transition. Jadaliyya, 11 February, http://www.jadaliyya.com/pages/index/10119/mohamed-morsi-mubarak_the-mythofegypts-democrati (accessed 4 February 2018).

Afify H (2013) The Acquiescing Opposition, Jadaliyya.com, 14 August, http://www.jadaliyya.com/Details/29306/The-Acquiescing-Opposition (accessed 18 October 2018).

Ahram Online (2012a) The anti-military kazeboon (liars) campaign brings anti-regime chanting and videos to the heart of the working class district of Imbaba in Cairo, 9 January, http://english.ahram.org.eg/UI/Front/MultimediaInner.aspx?NewsContentID=31322\& newsportalname=Multimedia (accessed 17 January 2018).

Ahram Online (2012b) 'No to Military Trials' marks 1st anniversary with music, testimonies, 27 February, http://english.ahram.org.eg/NewsContent/1/64/35541/Egypt/Politics-/No-to-MilitaryTrials-marks-st-anniversary-with-mu.aspx (accessed 17 January 2018).

Ahram Online (2013) Pro-Morsi rallies no longer acceptable: Egyptian cabinet, 31 July, http://english.ahram.org.eg/NewsContent/1/64/77907/Egypt/Politics/ProMorsi-rallies-no-longer-acceptable-Egyptian-cab.aspx (accessed 27 July 2016). 
Al-Nadim Centre for the Rehabilitation of Victims of Torture and Violence (2006) Torture in Egypt: A State Policy, 2003-2006, Cairo: Al-Nadim.

Al-Nadim Centre for the Rehabilitation of Victims of Torture and Violence (2002) Torture in Egypt: Facts and Testimonies, 1998-2002, Cairo: Al-Nadim.

Alaimo K (2015) How the Facebook Arabic Page "We Are All Khaled Said" Helped Promote the Egyptian Revolution. Social Media + Society, First Published October 8, 2015.

Albrecht H (2013) Egypt's 2012 Constitution: Devil in the Details, Not in Religion, USIP Peace Brief, 25 January, https://www.usip.org/sites/default/files/PB139-Egypt's\%202012\%20Constitution.pdf (accessed 16 October 2018).

Allam R (2012) Al-Sisi Praises Army's Role in Referendum, Daily News Egypt, 25 December, https://dailynewsegypt.com/2012/12/25/al-sisi-praises-armysrole-in-referendum/ (accessed 8 February 2018).

Alsharif A and Y Saleh (2013) Special Report: The Real Force Behind Egypt's 'Revolution of the State', Reuters, 10 October, https://uk.reuters.com/article/uk-egypt-interior-special-report/special-report-the-realforce-behind-egypts-revolution-of-the-state-idUKBRE99908720131010 (accessed 9 February 2018).

Amnesty International (2014), Egypt: Roadmap to repression: No end in sight to human rights violations, January, http://www.amnesty.org/en/library/info/MDE12/005/2014/en (accessed 25 March 2018). 
Aradau C (2004) Security and the Democratic Scene: Desecuritization and Emancipation, Journal of International Relations and Development 7(4): 388-413.

Associated Press (2012) Egypt's President Grants Himself Far-Reaching Powers, The Guardian, 22 November, https://www.theguardian.com/world/2012/nov/22/egypt-president-far-reachingpowers (accessed 1 February 2018).

Ayubi N (1993) Political Islam in the Arab World, London: Routledge. Ayubi N (1995) Over-stating the Arab State, London: I.B. Tauris. BBC (2013a) Egypt Army Chief Warns of 'State Collapse’ Amid Crisis, BBC.com, 29 January, http://www.bbc.co.uk/news/world-middle-east-21241753 (accessed 8 February 2018).

BBC (2013b) Profile: Egypt's Tamarod Protest Movement, BBC.com, 1 July, http://www.bbc.co.uk/news/world-middle-east-23131953 (accessed 9 February 2018).

Beinin J (2014) Civil Society, NGOs, and Egypt's 2011 Popular Uprising, South Atlantic Quarterly 113 (2): 396-406.

Bellin, E (2004) 'The Robustness of Authoritarianism in the Middle East', Comparative Politics, 36 (January): 139-57.

Bilgin P (2011) The Politics of Studying Securitization? The Copenhagen School in Turkey. Security Dialogue 42(4-5): 399-412.

Black I and P Kingsley (2013) Egypt: Resentment towards Brotherhood Fuels Crackdown Support, The Guardian, 16 August, https://www.theguardian.com/world/2013/aug/16/egypt-nationalism-muslimbrotherhood-crackdown (accessed 25 July 2016). 
Blaydes L (2010)

Elections and Distributive Politics in Mubarak's Egypt. Cambridge and New York: Cambridge University Press.

Browning C S and M McDonald (2011) The Future of Critical Security Studies: Ethics and the Politics of Security, European Journal of International Relations 19(2): 235-255.

Brownlee J (2007) Authoritarianism in an Age of Democratization. Cambridge and New York: Cambridge University Press.

Brownlee, J. (2011) Egypt's Incomplete Revolution: The Challenge of PostMubarak Authoritarianism. Jadaliyya.com, 5 July, http://www.jadaliyya.com/Details/24169/Egypt\%60s-Incomplete-Revolution-TheChallenge-of-Post-Mubarak-Authoritarianism

Buzan B, O Wæver and J de Wilde (1998) Security: A New Framework for Analysis. Boulder: Lynne Rienner.

Carr S (2013a) On Sheep and Infidels, Jadaliyya.com, 8 July, http://www.jadaliyya.com/Details/29011/On-Sheep-and-Infidels (accessed 16 October 2018).

Carr S (2013b) Army is the Only Answer, Say MOD Protesters, Jadaliyya.com, 1 July, http://www.jadaliyya.com/Details/28891/Army-is-the-OnlyAnswer,-Say-MOD-Protesters (accessed 18 October 2013).

Chalcraft J (2016) Popular Politics in the Making of the Middle East, Cambridge: Cambridge University Press. 
Charbel J (2017) State Responds to Recent Labor Protests with Heightened Repression and Exceptional Legal Measures, 24 January https://www.madamasr.com/en/2017/01/24/feature/politics/state-responds-to-recentlabor-protests-with-heightened-repression-and-exceptional-legal-measures/ (accessed 11 June 2017).

Chick K (2010) Beating death of Egyptian businessman Khalid Said spotlights police brutality, Christian Science Monitor, 18 June, https://www.csmonitor.com/World/Middle-East/2010/0618/Beating-death-ofEgyptian-businessman-Khalid-Said-spotlights-police-brutality (accessed 15 January 2018).

Chulov M and P Kingsley (2013) Egypt's Military Arrest Muslim Brotherhood Supreme Leader, The Guardian, 4 July, https://www.theguardian.com/world/2013/jul/04/egypt-military-arrest-warrantsmuslim-brotherhood (accessed 9 February 2018).

Cohen JL and Arato A (1992) Civil Society and Political Theory, Cambridge: The MIT Press.

Cox C (2016) Egypt's Loyal Opposition, Carnegie Endowment for International Peace, 29 June, http://carnegieendowment.org/sada/63961 (accessed 9 March 2018).

Dahan N and O Al-Mossallami (2018) 'Little Informants': Egypt Calls on Children to Spy on Neighbours, Middle East Eye, 7 February, http://www.middleeasteye.net/news/little-informants-egypts-interior-ministrycartoon-calls-children-be-informants-2084681494 (accessed 9 March 2018). 
Dorman, W J (2013) Egypt's 'civil society coup' and the resilience of the post-1952 order, Open Democracy, 10 October, https://www.opendemocracy.net/arab-awakening/wj-dorman/egypts-civil-societycoup-and-resilience-of-post-1952-order (accessed 9 March 2018).

Eagleton, T (1991) Ideology: An Introduction, London: Verso.

EIPR (Egyptian Initiative for Personal Rights) (2014) The Weeks of Killing: State Violence, Communal Fighting and Sectarian Attacks in the Summer of 2013, http://eipr.org/sites/default/files/reports/pdf/weeks_of_killing_en.pdf (accessed 27 July 2016).

El-Ghobashy M (2005) The Metamorphosis of the Egyptian Muslim Brothers, International Journal of Middle East Studies 37 (3): 373-395.

El-Sherif A (2014) The Egyptian Muslim Brotherhood's Failures, July, Washington, CD: Carnegie Endowment for International Peace.

El-Sisi A F (2013a) Statement, BBC.com, 4 July, http://www.bbc.com/news/world-middle-east-23175529 (accessed 1 November 2016).

El-Sisi A F (2013b), Speech of General Abdelfattah El-Sissy During the Graduation Ceremony of the Naval Academy Alexandria, 24 July, Al-Yum al-Saba', http://www.youm7.com/Article/NewsPrint/1177539 (accessed 1 June 2017).

El-Sisi A F (2014) Statement by President Abdel Fattah El-Sisi at Ceremony Marking His Inauguration, State Information Service, 9 June, http://www.sis.gov.eg/Story/78278 (accessed 9 March 2018). 
Elmasry M (2013) Unpacking Anti-Muslim Brotherhood Discourse, 28 June, Jadaliyya, http://www.jadaliyya.com/pages/index/12466/unpacking-anti-muslimbrotherhood-discourse (accessed 25 July 2016).

Encarnación O (2013) Even Good Coups Are Bad: Lessons for Egypt from the Philippines, Venezuela and Beyond, Foreign Policy, 9 July, https://www.foreignaffairs.com/articles/egypt/2013-07-09/even-good-coups-are-bad (accessed 16 November 2018).

ERTU (Egyptian Radio and TV Union) (1965) Gamal Abdel-Nasser on the Muslim Brotherhood, https://www.youtube.com/watch?v=TX4RK8bj2W0 (accessed 16 December 2016).

Ezzat D (2013) Getting Closer to Qatar, Al-Ahram Weekly, 16 January, http://weekly.ahram.org.eg/News/965.aspx (accessed 8 February 2018).

Femia J (2001) Civil Society and the Marxist Tradition in S Kaviraj and S Khilani (eds) Civil Society: History and Possibilities, Cambridge: Cambridge University Press, pp. 131-146.

Fisher M (2014) The real tragedy of Egyptian satirist Bassem Youssef's censorship is he played a role in it, Vox.com, 2 June, https://www.vox.com/2014/6/2/5772102/the-real-tragedy-of-egyptian-satirist-bassemyoussefs-censorship-is (accessed 16 October 2018).

Gandhi J and E Lust (2009) Elections under Authoritarianism, Annual Review of Political Science, 12: 403-422. 
Gramsci, A (1971) Selections from the Prison Notebooks, trans. and ed. By Quinton Hoare and Geoffrey Nowell-Smith, London: Lawrence and Wishart.

Greenwood M T and O Waever (2013) Copenhagen-Cairo on a Roundtrip: A Security Theory Meets the Revolution, Security Dialogue 44 (5-6): 485-506.

Gresh A (2015) I Was Arrested for Chatting in a Cairo Café, Al-Jazeera English, 15 November, https://www.aljazeera.com/indepth/opinion/2014/11/i-wasarrested-chatting-cairo-20141114175012955778.html (accessed 9 March 2018).

Guerin O (2018) The Shadow over Egypt, BBC, 23 February, http://www.bbc.co.uk/news/resources/idt-sh/shadow_over_egypt (accessed 7 March 2018).

Hamzawy A (2017) Legislating Authoritarianism: Egypt's New Era of Repression, March, Washington, DC: Carnegie Endowment for International Peace.

Hardig AC (2015) Beyond the Arab Revolts: Conceptualizing Civil Society in the Middle East and North Africa, Democratization 22(6): 1131-1153.

Heydemann S (2007), Social Pacts and the Persistence of Authoritarianism in the Middle East, in O Schlumberger (ed) Debating Arab Authoritarianism: Dynamics and Durability in Nondemocratic Regimes, Berkeley: University of California Press, pp. 21-38.

Holm U (2004) Algeria: Securitisation of State/Regime, Nation and Islam, in Stefano Guzzini and Dietrich Jung (eds) Contemporary Security Analysis and Copenhagen Peace Research. London: Routledge, 217-28.

Howeidy A (2015) Matarriya: Egypt's New Theatre of Dissent, Middle East Report, 4 June, http://www.merip.org/mero/mero060415 (accessed 11 June 2017). 
HRW (1992) Behind Closed Doors: Torture and Detention in Egypt. New York: Human Rights Watch.

HRW (1995) Egypt: Hostage-taking and Intimidation by Security Forces. New York: Human Rights Watch/Middle East.

HRW (1996) World Report 1996, Egypt, https://www.hrw.org/reports/1996/WR96/MIDEAST-02.htm\#P252_49204 (accessed 17 March 2017).

HRW (2001) Egypt: Human Rights Background, October, https://www.hrw.org/legacy/backgrounder/mena/egypt-bck-1001.htm (accessed 14 January 2018).

HRW (2012) Egypt: New Constitution Mixed on Support of Rights, 30 November, https://www.hrw.org/news/2012/11/30/egypt-new-constitution-mixedsupport-rights (accessed 16 October 2018).

HRW (2013) World Report 2012: Egypt, https://www.hrw.org/worldreport/2013/country-chapters/egypt (accessed 16 January 2018).

HRW (2014) All According to Plan: The Rab'a Massacre and Mass Killings of Protesters in Egypt, https://www.hrw.org/report/2014/08/12/all-accordingplan/raba-massacre-and-mass-killings-protesters-egypt (accessed 14 January 2018).

HRW (2015) Egypt: Counterterrorism law erodes basic rights, 19 August, https://www.hrw.org/news/2015/08/19/egypt-counterterrorism-law-erodes-basicrights (accessed 25 March 2018). 
HRW (2017) Egypt: Consolidating Repression under El-Sisi, 12 January, https://www.hrw.org/news/2017/01/12/egypt-consolidating-repression-under-al-sisi (accessed 11 June 2017).

HRW (Human Rights Watch) (2018) Egypt: Events of 2017 , https://www.hrw.org/world-report/2018/country-chapters/egypt (accessed 9 March 2018).

Hubbard B and M El-Sheikh (2013) Egyptian General Warns against Violence as Anniversary Approaches, New York Times, 23 June, http://www.nytimes.com/2013/06/24/world/middleeast/egyptian-general-warnsagainst-violence-as-anniversary-approaches.html (accessed 8 February 2018).

Hussein A (2012) Egypt: Mohamed Morsi cancels decree that gave him sweeping powers, The Guardian, 9 December, https://www.theguardian.com/world/2012/dec/09/egypt-mohamed-morsi-cancelsdecree (accessed 8 February 2018).

Hussein A and J Borger (2012) Egypt Opposition Group to Boycott 'Irresponsible' Vote on New Constitution, The Guardian, 9 December, https://www.theguardian.com/world/2012/dec/09/egypt-opposition-vote-constitution (accessed 1 February 2018).

Ibrahim I (2013) Rumours of a SCAF Comeback, Al-Akhbar English, 2 March, http://english.al-akhbar.com/node/15126 (accessed 8 February 2018).

Ismail S (2012) The Egyptian revolution against the police. Social Research 79(2): 435-462. 
Kandil H (2012) Soldiers, Spies and Statesmen: Egypt's Road to Revolt, London: Verso.

Ketchley N (2017) Egypt in a Time of Revolution, Cambridge: Cambridge University Press.

Ketchley N and T El-Rayyes (2017) On the Breadline in Sisi’s Egypt, Middle East Report, 29 March, http://www.merip.org/mero/mero032917 (accessed 11 June 2017).

Kienle E (2001) A Grand Delusion: Democracy and Economic Reform in Egypt, London: I.B. Tauris.

Kingsley P (2013) Protesters across Egypt Call for Mohamed Morsi to Go, 30 June, The Guardian, https://www.theguardian.com/world/2013/jun/30/mohamedmorsi-egypt-protests (accessed 7 March 2018).

Kingsley P and M Chulov (2013) Mohamed Morsi Ousted in Egypt's Second Revolution in Two Years, The Guardian, 4 July, https://www.theguardian.com/world/2013/jul/03/mohamed-morsi-egypt-secondrevolution (accessed 9 February 2018).

Kirkpatrick D (2012) Supporters and Opponents of Egypt's President Clash, New York Times, 12 October, http://www.nytimes.com/2012/10/13/world/middleeast/mohamed-morsis-critics-andbackers-clash-in-cairos-tahrir-square.html (accessed 26 January 2018).

Kirkpatrick D and Mayy El Sheikh (2012) Citing Deadlock, Egypt's Leader Seizes New Power and Plans Mubarak Retrial, New York Times, 22 November, 
https://www.nytimes.com/2012/11/23/world/middleeast/egypts-president-morsigives-himself-new-powers.html (accessed 18 October 2018).

Lorch J and Bunk B (2017) Using civil society as an authoritarian legitimation strategy: Algeria and Mozambique in comparative perspective, Democratization 24 (6): 987-1005.

Lust-Okar, E (2005) Structuring conflict in the Arab world: Incumbents, Opponents and Institutions. Cambridge: Cambridge University Press.

MadaMasr (2013a) Anti-Military Revolutionaries Take Part in Protests, 2 July, Jadaliyya.com, http://www.jadaliyya.com/Details/28912/Anti-MilitaryRevolutionaries-Take-Part-in-Protests (accessed 18 October 2018).

MadaMasr (2013b) Daqahlia Security Directorate Attacked, MadaMasr, 24 July, http://www.madamasr.com/news/daqahlia-security-directorate-attacked (accessed 27 July 2016).

MadaMasr (2013c) Observers Differ on Sisi’s Unexpected Call, MadaMasr, 24 July, http://www.madamasr.com/news/observers-differ-sisi\%E2\%80\%99sunexpected-call (accessed 27 July 2016).

MadaMasr (2016) Front States over 1000 Detained in Recent Demonstrations in Egypt, MadaMasr, 29 April, https://www.madamasr.com/en/2016/04/29/news/u/front-states-over-1000-detainedin-recent-demonstrations-in-egypt/ (accessed 11 June 2017).

McDonald M (2008) Securitization and the Construction of Security, European Journal of International Relations 14 (4): 563-587 
Mitchell R P (1969/1993) The Society of the Muslim Brothers, New York:

Oxford University Press.

Morsy A (2013) Towards Reconciliation, Al-Ahram Weekly, 18 July, http://weekly.ahram.org.eg/News/3400.aspx (accessed 25 March 2018).

Norton, AR (ed) (1994) Civil Society in the Middle East, Vol. 1, Leiden: Brill.

Norton, AR (ed) (1995) Civil Society in the Middle East, Vol. 2, Leiden: Brill.

Nunes J (2012) Reclaiming the political: Emancipation and critique in security studies, Security Dialogue 43(4): 345-361.

Ottaway M (2004) Civil Society. In Politics in the Developing World, ed. P J Burnell and V. Randall, 120-135. Oxford: Oxford University Press.

Pratt N (2004) Bringing Politics Back In: Examining the Links between Globalization and Democratization, Review of International Political Economy, 11: 2, pp. 311-336.

Pratt N (2005) Identity, Culture, and Democratization: The Case of Egypt, New Political Science, 27: 1, pp. 69-86.

Pratt N (2007a) Democracy and Authoritarianism in the Arab World, Boulder: Lynne Rienner.

Pratt N (2007b) The Queen Boat Case in Egypt: Sexuality, National Security and State Sovereignty, Review of International Studies, 33, pp. 129-44.

Pripstein Posusney M and M Penner Angrist, eds. (2005) Authoritarianism in the Middle East: Regimes and Resistance, Boulder: Lynne Rienner. 
Qiblawi T and B Jones (2017) Grief and Desperation in Egypt's Coptic Community after Palm Sunday Attacks, CNN.com, 10 April, https:/edition.cnn.com/2017/04/10/middleeast/egypt-coptic-community-griefanger/index.html (accessed 18 October 2018).

Rashed D (2016), Violence from Above, Violence from Below: The State and Policing Citizens in Mubarak's Egypt, in Bettina Koch, ed. State Terror, State Violence: Global Perspectives, Wiesbaden: Springer VS, pp. 93-113.

Rosefsky-Wickham C (2013) The Muslim Brotherhood: Evolution of an Islamist Movement, Princeton: Princeton University Press.

Sadiki L (1997) Towards Arab Liberal Governance: From the Democracy of Bread to the Democracy of the Vote, Third World Quarterly 18 (1): 127-148.

Sadowski Y (1993) The New Orientalism and the Democracy Debate, Middle East Report, no. 183: 14-21+40.

Schlumberger O (ed) (2007) Debating Arab Authoritarianism: Dynamics and Durability in Nondemocratic Regimes, Stanford: Stanford University Press.

Several Egyptian Human Rights Organizations. (2012) '"No" to constitution establishing political and theocratic tyranny; Egyptian rights groups reject draft constitution', http://www.cihrs.org/?p=5049\&lang=en (accessed 25 March 2018).

Shah, S (2008) Civil Society in Uncivil Places: Soft State and Regime Change in Nepal, Policy Studies 48, Washington, D.C.: East-West Center.

Shahine G (2012) 'Akhwana': Myth or Reality? Al-Ahram Weekly, 13 September. Republished on Masress.com, https://www.masress.com/en/ahramweekly/30706 (accessed 16 October 2018). 
Shams El-Din M (2015) A Year of Conspiracies, MadaMasr, 27 December, https://www.madamasr.com/en/2015/12/27/feature/politics/a-year-of-conspiracies/ (accessed 9 March 2018).

Shiulke S (2012) After One Hundred and a Few Days, A Book of Unfinished Theories, 14 October, http://samuliegypt.blogspot.com/2012/ (accessed 16 October 2018).

Soliman D and A Nour (2016) Egypt's Revolutionaries - Where are they now? BBC News, 25 January, http://www.bbc.co.uk/news/world-middle-east35401868 (accessed 9 March 2018).

Spencer R and M Samaan (2012) Mohammed Morsi Grants Himself Sweeping New Powers in Wake of Gaza, The Telegraph, 22 November, http://www.telegraph.co.uk/news/worldnews/africaandindianocean/egypt/9697347/M ohammed-Morsi-grants-himself-sweeping-new-powers-in-wake-of-Gaza.html (accessed 1 February 2018).

Stacher J (2015): Fragmenting states, new regimes: militarized state violence and transition in the Middle East, Democratization 22 (2): 259-275.

Tarek S (2011) SCAF hails security forces: warns of foreign plots, Ahram Online, 19 December, http://english.ahram.org.eg/NewsContent/1/64/29727/Egypt/Politics-/SCAF-hailssecurity-forces,-warns-of-foreign-plots.aspx (accessed 17 January 2018).

Vuori J A (2008) Illocutionary Logic and Strands of Securitization: Applying the Theory of Securitization to the Study of Non-Democratic Political Orders. European Journal of International Relations 14(1): 65-99. 
Waltz SE (1995) Human Rights and Reform: Changing the Face of North Africa, Berkeley: University of California Press.

Wilkinson C (2007) The Copenhagen School on Tour in Kyrgyzstan. Security Dialogue 38:1: 5-25.

Williams M C (2003) Words, Images, Enemies: Securitization and International Politics. International Studies Quarterly 47(4): 511-32.

Yahya M (2014) Choosing Security and Freedom in Egypt, Carnegie Endowment for International Peace, 1 July. Available at: http://carnegieendowment.org/2014/06/30/choosing-security-and-freedom-in-egyptpub-56052 (accessed 26 July 2016).

Youssef B (2013) Andma yati al-khitab ("When the speech comes"), Elbernameg, 1 March, YouTube, https://www.youtube.com/watch?v=6M0qc4uVp4M\&feature=youtu.be $($ accessed 16 October 2018).

Zubaida S (1992) Islam, the State and Democracy: Contrasting Conceptions of Society in Egypt, Middle East Report no. 179: 2-10.

\footnotetext{
${ }^{1}$ Emergency law was briefly lifted between May 1980 and October 1981. In June 2012, the emergency law expired and was not automatically renewed. However, in January 2013, the Morsi government introduced emergency law for 30 days in cities along the Suez Canal. In August 2013, following the Rabaa and Nahda square massacres, the interim government declared a month-long state of emergency. In
} 
April 2017, President El-Sisi introduced nationwide emergency law following attacks on two Coptic churches. It remains in place at the time of writing.

${ }^{2}$ For a comprehensive discussion of the constantly shifting relationship between the Mubarak regime and the Muslim Brotherhood, see Rosefsky Wickham 2013.

${ }^{3}$ El-Sisi was first elected president in May 2014 and re-elected in March 2018. 